www.jmscr.igmpublication.org

Index Copernicus Value: 79.54

ISSN (e)-2347-176x ISSN (p) 2455-0450

crossref DOI: https://dx.doi.org/10.18535/jmscr/v7i3.245

Journal Of Medical Science And Clinical Research

IGM Publication

An official Publication of IGM Publication

\title{
Hyperbillirubinemia as a Predictive Factor for Appendiceal Perforation in Acute Appendicitis: A Prospective Study
}

\author{
Dr Pankaj Kumar ${ }^{4}$, Dr Rounak Kumar \\ ${ }^{1}$ Associate Professor, ${ }^{2}$ Senior Resident, ${ }^{3,4,5}$ Junior resident \\ Department of General surgery, VIMSAR Burla \\ *Corresponding Author \\ Dr Dharbind Kumar Jha \\ Senior Resident, VIMSAR, BURLA, India \\ Mob no: 8763090706, Email: dr.dj4love@gmail.com
}

Dr Ashok Kumar Nayak ${ }^{1}$, Dr Dharbind Kumar Jha ${ }^{2 *}$, Dr Sanjeev Kumar Suman ${ }^{3}$

\begin{abstract}
The vermiform appendix is considered by most to be a vestigeal organ, its importance in surgery being only due to its propensity for imflammation that in a clinical syndrome called 'acute appendicitis'. Recently, it has been proposed that an elevated total bilirubin (TB) level could be used as a specific marker for the prediction of perforated appendicitis ${ }^{7}$. The rationale for this proposal is based on the hepatic congestion occurring during bacteria sepsis secondary to Gram negative bacteria. Our purpose of this study is to establish the correlation of total serum bilirubin with the appendiceal perforation in acute appendicitis and to compare the reliability of total bilirubin versus WBC count for suspected perforated appendicitis.
\end{abstract}

Keywords: Appendicitis, Hyperbilirubinemia.

\section{Introduction}

The vermiform appendix is considered by most to be a vestigeal organ, its importance in surgery being only due to its propensity for imflammation that in a clinical syndrome called 'acute appendicitis'. Curiously and astonishingly, the clinical entity of acute appendicitis was unknown for some two hundred odd years. The little organ called 'Vermiform Appendix', suggested by Verhegar, as a vestigial organ as regards to its digestive function, with its tiny and innocuous look deceived even the stalwarts of the-then medical fraternity.

In the early part of $19^{\text {th }}$ Century Acute appendicitis appeared as a dreaded scourge over the Western world. The incidence of acute appendicitis rose with a bang, due presumably to the outburst of industrialization, urbanisation and adapting to the habit of taking low fibre diet. It produced a significant morbidity and mortality rate. However, with the advent of potent antibiotics, safer anaesthetics and better understanding of the basic pathphysiology of the disorder, both mortality and morbility gradually fell down to a significant tolerable level.

Now-a-days the treatment of acute appendicitis has been standardized and offers a high percentage of cure but the same is not true as regards the clinic-pathological behavior of this malady. The matter is still unresolved even in 
these days. The picture is further obscured regarding the diagnosis of acute appendicitis, courtesy the varied presentations of the disorder. The vagaries of presentation and the variability of signs are such that even the most experienced surgeon may remove the normal appendix or 'sit on' the one that has perforated. The sequel of delayed treatment include a higher percentage of post-operative sepsis and a longer hospital stay. The high percentage of negative appendicectomy rate may have been justified by the valid fear which delayed diagnosis and resutted in appendicular perforation and subsequent generalized peritonitis.

However, such policy if negative appendicectomy is not without risk as $0.5-1 \%$ of appendicectomised patients may require surgery for intestinal obstruction caused mostly by postoperative adhesions. Postoperative complications of negative laparotomy, such as wound infections, abscess, fistula formation and incidional hernia nay be ashigh as $15 \%$.

Notwithstanding the advance in modern imaging and diagnosis laboratory investigations, the diagnosis of appendicitis remains essentially a clinical entity; requiring a mixture of observation, clinical acumen and surgical dictum. In this era accustomed to early and accurate preoperative diagnosis, acute appendicitis remains an enigmatic challenges and a reminder of the art of accurate surgical diagnosis . Ultrasonography and Computed Tomography have been used to complement the clinical diagnosis. However, the diagnosis can only be established by histopathological examinaition of the resected specimen appendix.

It is a commonly held belief that if it is left untreated, appendiceal inflammation will progress inevitable to gangrene, and ultimately to perforation and subsequent peritonitis. The time course of this progression varies from patient to patient. Although concern for perforation should be present when evaluating a patient with more than 24 hours of symptoms, the clinician must remember that perforation can develop more rapidly.

Perforated appendicitis is determined by patient's pre-hospital factors, such as the time period of symptoms which comprises the period of time from the onset of symptoms until the patient resents for medical evaluation of surgery ${ }^{1-2}$. The incidence of perforated appendicitis in adults has been reported from 13-37\% of higher. Research on the importance of in-hospital delay has determined that perforation does not accur in the hospital-phase of patients waiting surgery for appendicitis $^{1-2}$.

The risk of rupture is neiglible within the first 24 hours, climbing to $6 \%$ after 36 hours from the onset of symptoms and remains steady at approximately 5\% for each ensuing 12 hours period, establishing a 36 hours period from the onset of symptoms to surgery as a low risk period for appendiceal perforation ${ }^{1}$. Consequently inhospital delay is not an independent factor of perforation although delays may contribute if patients are left to wait undulu ${ }^{1-2}$. Perforated appendicitis has been associated with both earl and long-term complications, such as peritonitis, sepsis, small bowel obstruction, urinary retention, pelvic abscess and abdominal abscess formation and hence it's a accurate diagnosis and early treatment is of paramount importance to usher in a complication-free post-op period. Moreover, the removal of normal appendices has its known ethic economic, and legal implications.

Radiologic studies, such as computed tomography, magnetic imaging or ultrasonography, are highly sensitive and specific for diagnosis and at times confirmation of perforated appendicitis; but they are not always available in third world institutions or in emergency set-ups in developing countries where we must rely more on the clinical and laboratory tests to suspect appendicitis. As a consequence clinical and laboratory data of typical and atypical clinical presentations of appendicitis, laboratory test and inflammaty makers and diagnostic scores have been undertaken ${ }^{3}$. However, we as well as 
others believe that the diagnosis of appendicitis is mostly clinical ${ }^{4}$.

It is well established that when microbes invade the body, leucocytes defend it. This leads to increase in the leukocyte count. Bacterial invasion in the appendix leads to transmigration of bacteria and the release of TNF-alpha, IL6, and other cytokinins. These reach the liver via Superior mesenteric vein (SMV) and produce inflammation, abscess or dysfunction of liver either directly or indirectly by altering the hepatic blood flow ${ }^{6}$. The most commonly used laboratory tests to support the diagnosis of appendicitis are white blood cell count (WBC) and C-reactive protein $(\mathrm{CRP})^{3,5}$. These markers have been studies together with other parameters in an improve and predict the pre-operative diagnosis of perforated appendicitis, nevertheless, only an elevated CRP, a prolonged period of symptoms evolution, and fever have been identified as useful markers of perforation ${ }^{5}$.

Recently, it has been proposed that an elevated total bilirubin (TB) level could be used as a specific marker for the prediction of perforated appendicitis ${ }^{7}$. The rationale for this proposal is based on the hepatic congestion occurring during bacteria sepsis secondary to Gram negative bacteria, such as Escherichia, which is the main bacteria present in patients with appendicitis ${ }^{8}$. Consequently a low-grade hyperbiliribinaemia, often unnoticed in septic patients not presenting with clinically evident jaundice, is present in patient with Gram-negative infections.

Our purpose of this study is to establish the correlation of total serum bilirubin with the appendiceal perforation in acute appendicitis and to compare the reliability of total bilirubin versus WBC count for suspected perforated appendicitis.

\section{Materials \& Methods}

\section{Aims and Objectives}

1. To establish the correlation of total serum bilirubin with the appendiceal perforation in acute appendicitis.
2. To compare the reliability of total serum bilirubin versus total leukocyte count for suspected perforated appendicitis.

3. To avoid complications of acute appendicitis and possibilities of appendicular perforation by timely intervention of high-risk patients.

4. To assess the clinical, laboratory findings and operative findings by correlating with histopathological examination of resected appendix.

\section{Source of Data}

This study was performed on 125 patients who were clinically diagnosed of having acute appendicitis and were posted for appendicectomy in Post-Graduate Department of General Surgery, Veer Surendra Sai Medical College and Hospital, Burla, Sambalpur, Odisha, India, in collaboration with the Department of Pathology and the PostGraduate Department of Radiology of the same institution during the period from September 2016 to August 2018.

\section{Method of Collecting Data}

Sample Size: 125 cases of clinically diagnosed Acute Appendicitis

Sampling method: Simple Random Sampling Inclusion criteria

All patients, clinically diagnosed to have acute appendicitis, were subjected for appendicectomy in Veer Surendra Sai Medical College and Hospital, Burla, Sambalpur, Odisha, India.

\section{Exclusion criteria}

1. Patients with co-morbid conditions were not included in the study.

2. Patients who were managed conservatively were also excluded from the study.

3. Patients admitted for interval appendicectomy following recurrent appendicitis or appendicular mass previously treated conservatively, were also excluded.

4. Other diagnoses (peptic perforation, acute cholecystitis etc.) were also excluded by history, clinical examination and investigations. 
5. Patients were excluded if they have documented liver disease, history of alcoholism, haemolytic disease and other acquired or congenital biliary diseases.

Clinical diagnosis of acute appendicitis was done in the Post-Graduate Department of Surgery, based on symptoms of migratory pain, nausea and vomiting, anorexia, fever and signs of peritoneal inflammation like right iliac fossa tenderness, rebound tenderness and guarding. Once acute appendicitis was suspected, each patient was subjected to routine investigations as per the hospital protocol. Urine microscopy was performed in all cases. Elderly patients were subjected to further investigations as part of preanaesthetic work up including X-ray chest, ECG etc.

Total Serum bilirubin, Total leukocyte count and differential count were done in all cases. WBC count of more than 11,000 cells $/ \mathrm{mm}^{3}$ was considered positive. Ultrasonography of abdomen was done in all the cases to confirm diagnosis and to rule out other causes of acute abdomen. Total serum bilirubin more than $1.1 \mathrm{mg} / \mathrm{dL}$ was considered to be positive. No special preparation of the patient was required prior to sample collection by approved techniques. When there was delay, the sample was stored at $2-8^{\circ} \mathrm{C}$. Maximum period of storage was 72 hours.

Patients with strong suspicion of acute appendicitis were advised appendicectomy. After obtaining consent, patient was operated, and the appendicectomy specimen was sent for histopathological examination. The histopathology report was considered as the final diagnosis. The histopathologically positive cases among hyperbilirubinaemia positive group were considered true positives. The histopathologically negative cases in the same group were considered as false positives. The histopathologically positive cases among hyperbilirubinaemia negative group were considered false negatives. The histopathologically negative cases in the same group were considered as true negatives. Similarly WBC and USG were also classified as true and false positives and true and false negatives after correlating it with histopathology reports.

The evaluation of hyperbilirubinaemia. WBC and USG in the diagnosis of acute appendicitis and appendicular perforation was done as follows.

\begin{tabular}{|l|c|c|}
\hline \multirow{2}{*}{ Test } & \multicolumn{2}{|c|}{ HPE } \\
\cline { 2 - 3 } & Positive & Negative \\
\hline Positive & $\mathrm{a}$ & $\mathrm{b}$ \\
\hline Negative & $\mathrm{c}$ & $\mathrm{d}$ \\
\hline
\end{tabular}

Sensitivity $=(\mathrm{a} / \mathrm{a}+\mathrm{c}) \times 100$

Specificity $=(d / b+d) \times 100$

Predictive value of the positive test $=(\mathrm{a} / \mathrm{a}+\mathrm{b}) \mathrm{x}$ 100

Predictive value of the negative test $=(d / c+d) x$ 100

The patients were meticulously monitored in the post-operative period for any complications. All patients were followed up in the outpatient department every 2 weekly for a period of 8 weeks. During follow-up, they were enquired about the result of the operation and examined to detect the occurrence of late complications. The case study was done as per a proforma detailed in Annexure - I. The hospital ethical committee clearance was obtained prior to undertaking the study.

The present study was performed on 125 patients who have been clinically diagnosed as case of acute appendicitis and were posted for appendicectomy in tthe Post-Graduate Department of Surgery, VSS Medical College and Hospital, Burla during the period from September 2016 to August 2018. Apart from the routine investigations, all the 125 cases were subjected specifically to the following three investigations i.e. TLC, USG abdomen and Total Serum bilirubin to evaluate their role in accurately diagnosing a case of acute appendicitis and predicting the potential of serum bilirubin as a marker of appendiceal perforation in acute appendicitis. All the 100 cases were subjected to histopathological examination which was considered as gold standard and the final diagnosis. 
Various statistical methods like Descriptive and Chi-square test were applied. The following observations were made in the study.

\section{Age and Gender Distribution of Acute} Appendicitis And Appendicular Perforation:

The age of the patients ranged from 4 years to maximum of 70 years, with a mean age of 30.76 +/- 14.09 years. The maximum number of patients with acute appendicitis presented in the age group of 21-40 years (40\%) whereas patients with appendicular perforation presented mostly in age group of 21-30 years (7.2\%). The least number of patients were senn in patients of age group $<10$ and $>70$ years $(0.8 \%)$ both in acute appendicitis and appendicular perforation groups.

\begin{tabular}{|l|c|c|c|c|}
\hline & Minimum & Maximum & ean & $\begin{array}{c}\text { Standard } \\
\text { Deviation }\end{array}$ \\
\hline $\begin{array}{l}\text { Age } \\
\text { (years) }\end{array}$ & 4 & 70 & 0.769 & 14.0935 \\
\hline
\end{tabular}

In the present study, females were affected slightly more in acute appendicitis than males $(\mathrm{M}: \mathrm{F}=1: 1.15)$ while males predominated in appendicular perforation (M:F=3:1).

Table - 1: Age and Gender distribution of acute appendicitis and appendicular perforation $(n=125)$

\begin{tabular}{|l|c|c|c|c|c|c|}
\hline \multirow{2}{*}{$\begin{array}{l}\text { Age group } \\
\text { in years) }\end{array}$} & \multicolumn{3}{|c|}{ Acute appendicitis } & \multicolumn{3}{c|}{ Appendicular Perforation } \\
\cline { 2 - 7 } & Male & Female & Total & Male & Female & Total \\
\hline$<10$ & 0 & 1 & $1(0.8 \%)$ & 0 & 1 & $1(0.8 \%)$ \\
\hline $11-20$ & 6 & 10 & $16(12.8 \%)$ & 3 & 1 & $4(3.2 \%)$ \\
\hline $21-30$ & 15 & 12 & $27(21.6 \%)$ & 7 & 2 & $9(7.2 \%)$ \\
\hline $31-40$ & 10 & 3 & $23(18.4 \%)$ & 1 & 1 & $2(1.6 \%)$ \\
\hline $41-50$ & 6 & 7 & $13(10.4 \%)$ & 7 & 1 & $8(6.4 \%)$ \\
\hline $51-60$ & 3 & 3 & $6(4.8 \%)$ & 2 & 1 & $3(2.4 \%)$ \\
\hline$>60$ & 0 & 0 & 0 & 1 & 0 & $1(0.8 \%)$ \\
\hline Total & $40(32 \%)$ & $46(36.8 \%)$ & & $21(16.8 \%)$ & $7(5.6 \%)$ & \\
\hline
\end{tabular}

\section{Distribution of Symptoms and Signs}

Among all the clinical signs, right iliac fossa tenderness was seen in all cases $(100 \%)$ rebound tenderness in $46.4 \%$ cases and guarding/rigidity in
$27.1 \%$ of cases. Other peritoneal signs like Rovsing's sign were elicited in 4 cases and Psoas sign in 1 case only.

Table - 2: Distribution of symptoms and signs

\begin{tabular}{|l|c|c|c|c|c|c|}
\hline \multirow{2}{*}{$\begin{array}{l}\text { Age group } \\
\text { (in years) }\end{array}$} & \multicolumn{3}{|c|}{ Acute appendicitis } & \multicolumn{3}{c|}{ Appendicular Perforation } \\
\cline { 2 - 7 } & Male & Female & Total & Male & Female & Total \\
\hline$<10$ & 0 & 1 & $1(0.8 \%)$ & 0 & 1 & $1(0.8 \%)$ \\
\hline $11-20$ & 6 & 10 & $16(12.8 \%)$ & 3 & 1 & $4(3.2 \%)$ \\
\hline $21-30$ & 15 & 12 & $27(21.6 \%)$ & 7 & 2 & $9(7.2 \%)$ \\
\hline $31-40$ & 10 & 3 & $23(18.4 \%)$ & 1 & 1 & $2(1.6 \%)$ \\
\hline $41-50$ & 6 & 7 & $13(10.4 \%)$ & 7 & 1 & $8(6.4 \%)$ \\
\hline $51-60$ & 3 & 3 & $6(4.8 \%)$ & 2 & 1 & $3(2.4 \%)$ \\
\hline$>60$ & 0 & 0 & 0 & 1 & 0 & $1(0.8 \%)$ \\
\hline Total & $40(32 \%)$ & $46(36.8 \%)$ & & $21(16.8 \%)$ & $7(5.6 \%)$ & \\
\hline
\end{tabular}

Distribution of Cases As Per Histopathological Report

In the present study, 91.2\% (114 cases) were histopathologically found to be positive and 11 cases were negative on histopathology for various forms of acute appendicitis. Therefore the rate of negative appendicectomy in the present study was only $8.8 \%$. 
Table - 3: Distribution of cases as per histopathological report

\begin{tabular}{|l|c|}
\hline HPE Positive & HPE Negative \\
\hline $114(91.2 \%)$ & $11(8.8 \%)$ \\
\hline
\end{tabular}

Out of 114 cases histopathologically reported to be positive, the reporting was as follows:

\begin{tabular}{|l|c|}
\hline Normal Appendix & $11(8.8 \%)$ \\
\hline Acute appendicitis & $86(68.8 \%)$ \\
\hline Perforated appendix & $18(14.4 \%)$ \\
\hline Gangrenous appendicitis & $10(8 \%)$ \\
\hline Total & $114(91.2 \%)$ \\
\hline
\end{tabular}

In our study it was seen that the negative appendicectomy rate was higher in the female gender $(72.7 \%)$ as against males who formed only $27.3 \%$ of total cases negative appendicectomies.

\begin{tabular}{|l|c|c|}
\hline & Male & Female \\
\hline Normal appendix & 3 & 8 \\
\hline
\end{tabular}

\section{Role of Total WBC Count}

Out of 114 cases of acute appendicitis, 90 (78.94\%) had elevated total WBC count, rest 24 $(21.06 \%)$ patients had normal WBC count. The sensitivity of TLC was found to be $78.95 \%$; specificity 54.55\%; Positive Predictive value 94.74\% and Negative Predictive Value 20\%. The test was statically significant with the $\mathrm{P}$ value of 0.013

Table - 4A: Sensitivity, Specificity, Positive and Negative Predictive Value of TLC in all forms of Acute Appendicitis $(n=125)$

\begin{tabular}{|c|c|c|c|c|}
\hline \multirow[t]{2}{*}{ TLC } & \multicolumn{3}{|c|}{ Histopathology } & \multirow{5}{*}{$\begin{array}{l}\text { Sensitivity }=78.95 \% \\
\text { Specificity }=54.55 \% \\
\text { PPV }=94.74 \% \\
\text { NPV }=20 \% \\
\text { Chi-Square Value }=6.1679 \\
\text { Degrees of freedom }=1 \\
\text { P-value }=0.013\end{array}$} \\
\hline & $\begin{array}{c}\text { Acute } \\
\text { Appendicitis }\end{array}$ & Normal & Total & \\
\hline Elevated & 90 & 5 & 95 & \\
\hline Normal & 24 & 6 & 30 & \\
\hline Total & 114 & 11 & 125 & \\
\hline
\end{tabular}

PPV= Positive Perdictive Value; NPV= Negative Predictive Value; TLC $=$ Total Leukycyte Count.

The Sensitivty of TLC in predicting perforation among the acute appendicitis patient was found to be $21.43 \%$; specificity $23.3 \%$; Positive Predictive value $6.67 \%$ and Negative Predictive Value $8.33 \%$. The test was statistically significant with a $\mathrm{P}$ value of $<0.0001$.

Table - 4B: Sensitivity, Specificity, Positive and Negative Predictive Value of TLC in differentiating Gangrenous / Perforated from Non-perforated Appendicitis $(n=114)$

\begin{tabular}{|c|c|c|c|c|}
\hline \multirow[t]{2}{*}{ TLC } & \multicolumn{3}{|c|}{ Histopathology } & \multirow{5}{*}{$\begin{array}{l}\text { Sensitivity }=21.43 \% \\
\text { Specificity }=2.33 \% \\
\text { PPV }=6.67 \% \\
\text { NPV }=8.33 \% \\
\text { Chi-Square Value }=73.882 \% \\
\text { Degrees of freedom }=1 \\
\text { P-value }<0.0001\end{array}$} \\
\hline & $\begin{array}{c}\text { Perforated/Gangrenous } \\
\text { Appendicitis }\end{array}$ & $\begin{array}{c}\text { Non-perforated } \\
\text { Appendicitis }\end{array}$ & Total & \\
\hline Elevated & 6 & 84 & 90 & \\
\hline Normal & 22 & 2 & 24 & \\
\hline Total & 28 & 86 & 114 & \\
\hline
\end{tabular}

PPV= Positive Predictive Value; NPV= Negative Predictive Value; TLC $=$ Total Leukocyte Count. 


\section{Role of Total Serum Bilirubin Levels}

Out of 114 cases of acute appendicitis, 65 $(57.01 \%)$ had elevated total serum bilirubin, rest 49 (42.99\%) patients had normal bilirubin level. The sensitivity of the test was found to be
57.02\%; specificity 81.82\%; Positive Predictive value $97.01 \%$ and Negative Predictive Value $15.52 \%$. The test was statistically significant with the $\mathrm{P}$ value of $<0.0136$.

Table - 5A: Sensitivity, Specificity, Positive and Negative Predictive Value of Total Serum Bilirubin in all forms of Acute Appendicitis $(n=125)$

\begin{tabular}{|c|c|c|c|c|}
\hline \multirow{2}{*}{$\begin{array}{l}\text { Total Serum } \\
\text { Bilirubin }\end{array}$} & \multicolumn{3}{|c|}{ Histopathology } & \multirow{5}{*}{$\begin{array}{c}\text { Sensitivity }=57.02 \% \\
\text { Specificity }=81.82 \% \\
\text { PPV }=97.01 \% \\
\text { NPV }=15.52 \% \\
\text { Chi-Square Value }=6.0837 \\
\text { Degrees of freedom }=1 \\
\text { P-value }=0.0136\end{array}$} \\
\hline & $\begin{array}{c}\text { Acute } \\
\text { Appendicitis }\end{array}$ & Normal & Total & \\
\hline $\begin{array}{l}\text { Elevated } \\
(>1.1 \mathrm{mg} / \mathrm{dL})\end{array}$ & 65 & 3 & 67 & \\
\hline Normal & 49 & 9 & 58 & \\
\hline Total & 114 & 11 & 125 & \\
\hline
\end{tabular}

PPV= Positive Predictive Value; NPV= Negative Predictive Value

The sensitivity of the total serum bilirubin in predicting perforation among the acute appendicitis patients was found to be $89.29 \%$; specificity 53.49\%; Positive Predictive value
$38.46 \%$ and Negative Predictive Value $93.88 \%$. The test was statistically significant with the $\mathrm{P}$ Value of $<0.0001$.

Table - 5B: Sensitivity, Specificity, Positive and Negative Predictive Value of Total Serum Bilirubin in differentiating Gangrenous / Perforated from Non-perforated Appendicitis ( $n=114)$

\begin{tabular}{|c|c|c|c|c|}
\hline \multirow{2}{*}{$\begin{array}{l}\text { Total Serum } \\
\text { Bilirubin }\end{array}$} & \multicolumn{3}{|c|}{$\begin{array}{l}\text { Histopathology } \\
\end{array}$} & \multirow{5}{*}{$\begin{array}{l}\text { Sensitivity }=89.29 \% \\
\text { Specificity }=53.49 \% \\
\text { PPV }=38.46 \% \\
\text { NPV }=93.88 \% \\
\text { Chi-Square Value }=15.769 \% \\
\text { Degrees of freedom }=1 \\
\text { P-value }<0.0001\end{array}$} \\
\hline & $\begin{array}{c}\text { Perforated/Gangrenous } \\
\text { Appendicitis }\end{array}$ & $\begin{array}{l}\text { Non-perforated } \\
\text { Appendicitis }\end{array}$ & Total & \\
\hline $\begin{array}{l}\text { Elevated } \\
(>1.1 \mathrm{mg} / \mathrm{dL})\end{array}$ & 25 & 40 & 65 & \\
\hline Normal & 3 & 46 & 49 & \\
\hline Total & 28 & 86 & 114 & \\
\hline
\end{tabular}

$\mathrm{PPV}=$ Positive Predictive Value; NPV= Negative Predictive Value

\section{Role of Abdominal Ultrasonography}

Out of 114 cases of acute appendicitis, 106 (92.98\%) had USV findings suggestive of acute appendicitis; rest $8(7.02 \%)$ patients had normal abdominal scan. The sensitivity, specificity,
Positive Predictive value and Negative Predictive Values are $92.98 \%, 72.73 \%, 97.25 \%$ and $50 \%$ respectively. The rest significant as the $\mathrm{P}$ value was $<0.0001$.

Table - 6: Sensitivity, Specificity, Positive and Negative Predictive Value of Abdominal USG in all forms of Acute Appendicitis ( $n=125)$

\begin{tabular}{|c|c|c|c|c|}
\hline \multirow{2}{*}{$\begin{array}{l}\text { Abdominal } \\
\text { USG }\end{array}$} & \multicolumn{3}{|c|}{ Histopathology } & \multirow{5}{*}{$\begin{array}{l}\text { Sensitivity }=92.98 \% \\
\text { Specificity }=72.73 \% \\
\text { PPV }=97.25 \% \\
\text { NPV }=50 \% \\
\text { Chi-Square Value }=38.8079 \\
\text { Degrees of freedom }=1 \\
\text { P-value }=0.0001\end{array}$} \\
\hline & $\begin{array}{c}\text { Acute } \\
\text { Appendicitis }\end{array}$ & Normal & Total & \\
\hline Elevated & 106 & 3 & 109 & \\
\hline Normal & 8 & 8 & 16 & \\
\hline Total & 114 & 11 & 125 & \\
\hline
\end{tabular}

PPV= Positive Predictive Value; NPV= Negative Predictive Value 
Distribution of Cases According to the Level of Total Serum Bilirubin (TSB) and Total Leukocyte Count (TLC)

Of the 125 patients, 95 (76\%) cases were found to have elevated TLC and it was normal in 30 (24\%) cases. Among the cases that had elevated TLC, 90
(94.73\%) had a positive histology for various forms of acute appendicitis and the remaining 5 (5.27\%) had normal histology. Among 30 cases that had normal TLC, 24 had a positive histology for various forms of acute appendicitis, while the remaining 6 had normal histology.

Table - 7: Distribution of cases according to the level of Total Serum Bilirubin (TSB) and Total Leukocyte Count (TLC) $(n=125)$

\begin{tabular}{|c|c|c|c|c|}
\hline \multirow[t]{3}{*}{ Type of Appendix } & \multicolumn{2}{|c|}{ Total Serum Bilirubin } & \multicolumn{2}{|c|}{ Total Leukocyte Count } \\
\hline & $<1.1 \mathrm{mg} / \mathrm{dL}$ & $>1.1 \mathrm{mg} / \mathrm{dL}$ & $<\underset{\text { cells } / \text { uL }}{111 \times 10^{3}}$ & $\begin{array}{l}>11 \times 10^{3} \\
\text { cells/uL }\end{array}$ \\
\hline & No(\%) & No(\%) & No(\%) & No(\%) \\
\hline Acute Appendicitis & $46(36.8 \%)$ & $40(32 \%)$ & $2(1.6 \%)$ & $84(67.2 \%)$ \\
\hline Gangrenous Appendix & $2(1.6 \%)$ & $8(6.4 \%)$ & $8(6.4 \%)$ & $2(1.6 \%)$ \\
\hline Perforated Appendix & $1(0.8 \%)$ & $17(3.6 \%)$ & $14(11.2 \%)$ & $4(3.2 \%)$ \\
\hline Normal Appendix & $9(7.2 \%)$ & $2(1.6 \%)$ & $6(4.8 \%)$ & $5(4 \%)$ \\
\hline Total & 58 & 67 & 30 & 95 \\
\hline
\end{tabular}

Out of 125 patients, $67(53.6 \%)$ were found to have elevated Total Serum Bilirubin, while it was within normal limits in $58(46.4 \%)$ cases. Among the cases that had elevated TSB, 65 (97.01\%) had a positive histology for various forms of acute appendicitis, while rest $2(2.99 \%)$ cases were normal on histology. In cases with normal TSB, 49 had positive histology for various forms of acute appendicitis, while 9 had normal histology.

\section{Comparison between total serum bilirubin and total leukocyte count as laboratory markers of appendicular perforation}

In the present study, it was observed that total serum bilirubin was a better predictive factor for appendiccal perforation in acute appendicitis than total leukocyte count as the sensitivity, specificity, Positive Predictive Value and Negative Predictive Value of total serum bilirubin was found to be $89.29 \%$ against $21.43 \%$; $53.49 \%$ vs $2.33 \%$; $38.46 \%$ vs. $6.67 \%$ and $93.88 \%$ vs. $8.33 \%$ of total leukocyte count respectively.

Table - 8: Comparison between Total Serum Bilirubin and Total Leukocyte Count as laboraoty markers of Appendicular Perforation

\begin{tabular}{|l|c|c|c|c|}
\hline Leucocyte value & Sensitivity(\%) & Specificity(\%) & PPV(\%) & NPV(\%) \\
\hline TLC $>11 \times 10^{3}$ & 21.43 & 2.33 & 6.67 & 8.33 \\
\hline Total Bilirubin $>1.1 \mathrm{mg} / \mathrm{dL}$ & 89.29 & 53.49 & 38.46 & 93.88 \\
\hline
\end{tabular}

PPV= Positive Predictive Value; NPV= Negative Predictive Value; vs.= versus

\section{Prognosis}

The overall prognosis in our study was good without any mortality in 125 patients. However, morbidity was mainly due to local complications as depicted below in tubular form. 
Table - 9: Post-operative Complications

\begin{tabular}{|l|c|c|c|}
\hline \multirow{2}{*}{ Complications } & \multicolumn{2}{|c|}{ Number of Patients } & \multirow{2}{*}{$\begin{array}{c}\text { Total } \\
(\mathbf{n = 1 1 4})\end{array}$} \\
\cline { 2 - 3 } & $\begin{array}{c}\text { Non-perforated } \\
\text { appendicitis } \\
(\mathbf{n = 8 6 )}\end{array}$ & $\begin{array}{c}\text { Perforated/Gangrenous } \\
\text { appendicitis } \\
(\mathbf{n = 2 8})\end{array}$ & \\
\hline Minor Wound Infection & 5 & 10 & $\mathbf{1 5}(\mathbf{1 3 . 1 5 \% )}$ \\
\hline Wound Infection & 4 & 6 & $10(8.77 \%)$ \\
\hline Pulmonary Complications & 0 & 2 & $2(1.75 \%)$ \\
\hline Prolonged Ileus & 1 & 4 & $5(4.38 \%)$ \\
\hline Delayed Intestinal Obstruction & 0 & 2 & $2(1.75 \%)$ \\
\hline Total & $\mathbf{1 0}(\mathbf{8 . 7 7 \%})$ & $\mathbf{2 4}(\mathbf{2 1 . 0 5 \% )}$ & \\
\hline
\end{tabular}

Commonest complication was minor wound infection $(13.15 \%)$, followed by wound sepsis $(8.77 \%)$ and prolonged ileus $(4.38 \%)$. There was pulmonary complication in $2(1.75 \%)$ of cases. In $2(1.75 \%)$ cases, there were reports of delayed intestinal obstruction after a period of 6 months.

The complications were found to occur more in gangrenous or perforated appendicitis $(21.05 \%)$ than in non-perforated appendicitis patients $(8.77 \%)$

\section{Discussion}

The primary aim the present study was to establish the role of hyperbilirubinaemia as a predictive factor for appendiceal perforation in acute appendicitis patients. The present study was performed in the Post-Graduate Department of General Surgery, VSS Medical College and Hospital, Burla during the period from July 2010 to May 2012, on 125 patients who have been clinically diagnosed of acute appendicitis. The diagnosis was confirmed by operative and histopathological examination of the resected appendix.

\section{Age and Sex}

Out of 125 patients, 40 (32\%) were males and 46 $(36.8 \%)$ were females who were diagnosed to have non-perforated acute appendicitis, showing a slightly more incidence of uncomplicated acute appendicitis in females. But appendicular perforation was seen in $21(16.8 \%)$ males and 7 (5.6\%) female patients, clearly demonstrating the male predominance. Acute appendicitis has been found most frequently in the age group of 21-40 years and the rate of appendicular perforation reaches its peak in the group 21-30 years and 4150 years in this study.

Clinical diagnosis was found to be correct in $91.2 \%$ of cases and hence the rate of negative laparotomies for acute appendicitis in our study is merely $8.8 \%$. According to literature, accuracy of clinical examination ranges from 75 to $97 \%$. Depending upon the experience of the surgeon, the reported with other studies are as follows.

Table - 10: Comparison of accuracy of clinical diagnosis in acute appendicitis other studies

\begin{tabular}{|l|c|c|c|c|}
\hline & $\begin{array}{c}\text { Study } \\
\text { Group }\end{array}$ & $\begin{array}{c}\text { HPE } \\
\text { Positive }\end{array}$ & $\begin{array}{c}\text { HPE } \\
\text { Negative }\end{array}$ & $\begin{array}{c}\text { Negative } \\
\text { appendectomy }\end{array}$ \\
\hline Gurleyik et al & 108 & $90(83.3 \%)$ & $18(16.7 \%)$ & $16.7 \%$ \\
\hline Shakhatreh HS et al & 98 & $89(91 \%)$ & $9(9 \%)$ & $9(9 \%)$ \\
\hline Afsar S et al & 78 & $63(80 \%)$ & $12(20 \%)$ & $20 \%$ \\
\hline Oosterhius et al & 125 & $101(80.8 \%)$ & $24(19.2 \%)$ & $19.2 \%$ \\
\hline Khan MN et al & 259 & $222(85.7 \%)$ & $37(14.3 \%)$ & $14.3 \%$ \\
\hline Svend Dueholm et al & 100 & 59 & 41 & $41 \%$ \\
\hline Present study & $\mathbf{1 2 5}$ & $\mathbf{1 1 4}(\mathbf{9 1 . 2 \%})$ & $\mathbf{1 1 ( 8 . 8 \% )}$ & $\mathbf{8 . 8 \%}$ \\
\hline
\end{tabular}

Out of 11 patients who were HPE negative, 8 $(72.7 \%)$ were females and $3(27.3 \%)$ were males.
This observation is supported in study by Gronrous and Gronrous ${ }^{68}$. In their study group 
(100), $62 \%$ female and $38 \%$ male patients had negative appendicectomies. The diagnosis accuracy of acute appendicitis in women of child bearing are group was low because of many conditions mimicking appendicitis. Among the 114 patients reported to be positive on HPE examination, $86(68.8 \%)$ cases were reported to have inflamed appendix, rest $28(22.4 \%)$ cases were reported to have complication of acute appendicitis (i.e. 10 gangrenous appendicitis and 18 perforated appendicitis).

\section{WBC Count and Acute Appendicitis}

The sensitivity, specificity, predictive value of positive test and predictive value of negative test of WBC in our study is $78.75 \%, 80 \%, 94 \%$ and $48.48 \%$ respectively. Our results are in accordance with other studies as shown in the table.

Table 11: Comparison or role of WBC count in diagnosis of uncomplicated acute appendicitis with other studies

\begin{tabular}{|l|c|c|c|c|}
\hline & Sensitivity(\%) & Specificity(\%) & PPV(\%) & NPV(\%) \\
\hline Dueholm et al & 83 & & & 88 \\
\hline MN khan et al & 83 & 62.1 & 92 & \\
\hline Marchand et al & $81-84$ & & & \\
\hline Hoffman et al & $81-84$ & & & \\
\hline Doraiswamy et al & 42 & & & \\
\hline Pieper et al & 66.7 & & & \\
\hline Andrew Emanuel et al & 82 & 60 & 90 & 42 \\
\hline Present Study & $\mathbf{7 8 . 9 5}$ & $\mathbf{5 4 . 5 5}$ & $\mathbf{9 4 . 7 4}$ & $\mathbf{2 0}$ \\
\hline
\end{tabular}

PPV = Positive Predictive Value; NPV= Negative Predictive Value

Marchand et $\mathrm{al}^{77}$ concluded in their study that WBC $>10.5 \times 10^{9} / \mathrm{L}$ was one of the single best tests for diagnosis of acute appendicitis with highest sensitivities amongst all the tests examined (81$84 \%)$.

According to study done by JM Gronroos et $\mathrm{al}^{68}$. WBC was the test of choice in diagnosing uncomplicated acute appendicitis, however it is a poor predictor of protracted inflammation. This is supported in study by David and Birchley et al59. The WBC count when done individually distinguishes normal appendix from uncomplicated acute appendicitis, but does not distinguish uncomplicated from complicated appendicitis. Coleman $\mathrm{C}$ et al62 reported that
WBC is a poor predictor of severity of disease. Vermeulen et al64 after evaluating 221 patients concluded that WBC could did not significantly influence the surgical decision making.

In our study association of WBC count and acute appendicitis has shown to be significant with $\mathrm{P}$ value of 0.013 .

\section{Role of WBC Count and total Serum Bilirubin} in Perforated/Gangrenous Appendicitis:

The sensitivity, specificity, predictive value of positive test and predictive value of negative test of WBC in our study is $78.75 \%, 80 \%, 94 \%$ and $48.48 \%$ respectively. Our results are compared with other studies as shown in the table.

Table 12: Comparison of role of WBC count and total serum bilirubin in diagnosis of Gangrenous/Perforated appendicitis with other studies

\begin{tabular}{|l|c|c|c|c|c|}
\hline & & Sensitivity(\%) & Specificity(\%) & PPV(\%) & NPV(\%) \\
\hline \multirow{3}{*}{ K. Atahan et al } & WBC & 82.22 & 44.77 & 21.89 & 94.48 \\
\cline { 2 - 6 } & Bilirubin & $\mathbf{7 7 . 7 7}$ & $\mathbf{8 7 . 2 1}$ & $\mathbf{4 5 . 1 6}$ & $\mathbf{9 6 . 6 6}$ \\
\hline \multirow{2}{*}{ Salamat khan } & WBC & 77 & 50 & 97.8 & 7.4 \\
\cline { 2 - 6 } & Bilirubin & $\mathbf{8 0}$ & $\mathbf{1 0 0}$ & $\mathbf{1 0 0}$ & $\mathbf{1 4}$ \\
\hline \multirow{2}{*}{ Marcelo et al } & WBC & 61 & 36 & & \\
\cline { 2 - 6 } & Bilirubin & $\mathbf{5 7}$ & $\mathbf{5 1}$ & & \\
\hline \multirow{2}{*}{$\begin{array}{l}\text { Andrew Emanuel } \\
\text { et al }\end{array}$} & WBC & 93 & 19 & $\mathbf{2 1}$ & $\mathbf{9 2}$ \\
\cline { 2 - 6 } & Bilirubin & $\mathbf{6 0}$ & $\mathbf{7 0}$ & 6.67 & 8.33 \\
\hline \multirow{2}{*}{ Present Study } & WBC & 21.43 & 2.33 & $\mathbf{3 8 . 4 6}$ & $\mathbf{9 3 . 8 8}$ \\
\cline { 2 - 6 } & Bilirubin & $\mathbf{8 9 . 2 9}$ & $\mathbf{5 3 . 4 9}$ & &
\end{tabular}

PPV = Positive Predictive Value; NPV= Negative Predictive Value 
In our study, the sensitivity, specificity, predictive value of positive test and predictive value of negative test of total serum bilirubin in differentiating gangrenous or perforated from uncomplicated appendicitis is $89.29 \%, 53.49 \%$, $38.46 \%$ and $93.88 \%$ respectively. Our results are in accordance with other studies as shown in the table.

$\mathrm{K}$ Atahan et $\mathrm{al}^{58}$ in their retrospective study conducted over 351 patients between January 2006 and December 2009 concluded that WBC and total bilirubin values were differential in the diagnosis of acute appendicitis and acute gangrenous or perforated appendicitis. The specificity of acute high bilirubin levels for perforated appendicitis was $87.21 \%$, whereas the specificity of WBC was $44.77 \%$. The AUC for total bilirubin of $>0.8$ and for WBC counts of $>0.70$ demonstrated that total bilirubin is a good discriminator and more valuable than WBC count for discriminating between perforated appendicitis and acute appendicitis or lymphoid hyperplasia.

Salamat $\mathrm{Khan}^{57}$ in his prospective study of 122 patients between December 2004 and January 2008 opined that elevated total serum bilirubin is a better laboratory test (with $100 \%$ specificity, $80 \%$ sensitivity and $81.14 \%$ overall diagnostic accuracy) than TLC (with 50\% specificity, 77\% sensitivity and $76.22 \%$ overall diagnostic accuracy) in the diagnosis of appendicular perforation in acute appendicitis.

Marcelo A. Et al ${ }^{59}$ conducted a prospective study over 134 patients from October 2007 to September 2008. They concluded that WBC is more important in supporting the clinical diagnosis of appendicitis (perforated or nonperforated). But because it has a low sensitivity and specificity, it has little value in the diagnosis of perforated appendicitis. However, their study was contrasting to others in that they cannot recommend hyperbiliribunaemia as a predictor of perforation in acute appendicitis since other serologic tests (CRP), and clinical variables (SIRS, time period of symptoms evolution) performed better than TB in the ROC curve analysis, and have a better sensitivity to predict perforation in patients with appendicitis.

Andrew Emmanuel et $\mathrm{al}^{60}$ in their retrospective study of 472 patients demonstrated that hyperbilirubinaemia had a specificity of $88 \%$ and a positive predictive value of $91 \%$ for acute appendicitis. Patients with appendicitis who had a perforated or gangrenous appendix had higher mean bilirubin levels $(\mathrm{p}=0.01)$ and were more likely to have hyperbilirubinaemia $(\mathrm{p}<0.001)$. The specificity of hyperbilirubinaemia for perforation or gangrene was $70 \%$. The specifications of white cell count and C-reactive protein were less than hyperbilirubinaemia for simple appendicitis $(60 \%$ and $72 \%$ ) as well as perforated or gangrenous appendicitis (19\% and 36\%). Hence serum bilirubin is a better marker of appendicular perforation than CRP and WBC.

The present study is supported by other studies like Andrew Emmanuel et al, K Atahan et al, Salamat Khan etc. in that Total Serum Bilirubin (sensitivity $89.29 \%$; specificity $53.49 \%$; PPV $38.46 \%$ and NPV $93.88 \%$ ) is a better marker for predicting perforation in acute appendicitis than total WBC count (sensitivity $21.43 \%$; specificity 2.33\%; PPV $6.67 \%$ and NPV 8.33\%). Hence, serum bilirubin should be included in the assessment of patients with suspected appendicitis.

\section{USG Abdomen and Acute Appendicitis}

The sensitivity, specificity, predictive value of positive test and predictive value of negative test in our study is $92.98 \%, 72.73 \%, 97.25 \%$ and $50 \%$ respectively. Comparison of the overall performance of USG as an investigation of acute appendicitis is compared to the data reported in literature in the following table. 
Table 13: Comparison of role of USG abdomen in diagnosis of acute appendicitis with other studies

\begin{tabular}{|l|c|c|c|c|}
\hline & $\begin{array}{c}\text { Sensitivity } \\
(\%)\end{array}$ & $\begin{array}{c}\text { Specificity } \\
(\%)\end{array}$ & $\begin{array}{c}\text { PPV } \\
(\%)\end{array}$ & $\begin{array}{c}\text { NPV } \\
(\%)\end{array}$ \\
\hline A.Shirazi et al & 93.7 & 94.5 & 94.4 & 92.5 \\
\hline Dr david et al & 85.5 & 84.4 & 88.3 & 80.1 \\
\hline H.s. Fung et al & 75.9 & 89.7 & 73.2 & 91 \\
\hline West et al & 29 & 92 & 83 & \\
\hline Present study & $\mathbf{9 2 . 9 8}$ & $\mathbf{7 2 , 7 3}$ & $\mathbf{9 7 . 2 5}$ & $\mathbf{5 0}$ \\
\hline
\end{tabular}

$\mathrm{PPV}=$ Positive Predictive Value; NPV= Negative Predictive Value

Most of the above mentioned studies support the fact that USG abdomen and pelvis is an accurate, safe and reliable method in the diagnosis of suspected cases of acute appendicitis than can help to minimize negative appendicectomies and perforation rate.

The study by Zoller WG et $\mathrm{al}^{103}$ states that negative laparotomies could be decreased by $7 \%$ and possible differential diagnosis could be either confirmed or ruled out by using ultrasound. It is especially useful in woman because the list for differential diagnostic for appendicitis is expanded due to many acute gynaecological conditions mimicking acute appendicitis. Bendek et al. found that women in particularly are benefited most from of preoperative imaging, with significant reduction in negative appendicectomy rate than in those who undergo no preoperative investigation. David et $\mathrm{al}^{89}$ in his study stated that USG abdomen and pelvis is safe, and useful investigation, but in his study $24 \%$ patients with normal USG had acute appendicitis; therefore they stated than USG abdomen cannot be relied upon to exclude appendicitis.

Our study showed high association between USG as a diagnostic tool for acute appendicitis.

Hyperbilirubinaemia has been inadequately investigated as a potential laboratory indicator for the preoperative diagnosis of perforated appendicitis. Both increased bilirubin production and alternations in bilirubin clearance can lead to bilirubin accumulation and may be involved in the hyperbilirubinaemia observed in patients with appendix perforation ${ }^{58}$.

The hepatocellular dysfunction/damage in sepsis may be either due to bacteria, its toxin or cytokines. The agent reaches from infamed gut via portal vein or lymphatic with the process of transmigration or translocation.

It has frequently been demonstrated that several bacterial infections accompany hepatic dysfunction, to the extent that anomalies in bile flow and bile acid production arise as a result. This may lead, in turn, to hyperbilirubinaemia, which is a well-known adverse event associated with bacterial infection, particularly in patients with sepsis. These patients together with those who have extrahepatic bacterial infections demonstrate cholestasis, induced by nitric oxide (NO) and a proinflammatory cytokine via detrimental hepatocellular and ductal bile formation $^{58}$.

In addition, the most common bacterial species cultured from the appendix walls of patients with acute appendicitis are E. Coli and Bacteroides fragilis, two species that inhabit microcirculation and cause sinusoidal damage. Lipopolysaccharides (LPS) associated with E. Coli can affect hepatocyte uptake and bile acid secretion. In addition E. Coli infection leads to regular haemolysis of erythrocytes. Increased bilirubin load and, perhaps, the development of hyperbilirubinaemia may be a consequence of this mechanism $^{58}$.

It has also been noted that hepatocellular function is depressed during early stage of sepsis despite the increased cardiac output and hepatic blood flow and decrease peripheral resistance. The depression of hepatocellular function in early hyperdynamic stage of sepsis does not appear to be due to reduction in hepatic perfusion but is associated with elevated levels of circulating proinflammatory cytokines such as TNF and interleukin-6. Thus up-regulation of TNF-alpha 
and/or IL-6 may be responsible for producing hepatocellular dysfunction during early hyperdynamic stage of sepsis.

The present findings can be applied practical situations in that a patient with a suspected acute appendicitis, who is a male, has a WBC count $>11 \times 10^{3}$ cells/uL and also hyperbilirubinaemia > $1.1 \mathrm{mg} / \mathrm{dL}$ should be considered as a potential case of perforated appendicitis

The present study was performed on 125 patients who have been clinically diagnosed as cases of acute appendicitis and were posted for appendicectomy in the Post-Graduate Department of General Surgery, VSS Medical College \& Hospital, Burla during the period from September 2016 to August 2018.

The primary aim of the present study was to establish the role of hyperbilirubinaemia as a predictive factor for appendiceal perforation in acute appendicitis patients. All the patients were subjected to histopathological examination of the removed appendix which was taken to be the gold standard of retrospective diagnosis.

Out of 125 patients, females were affected slightly more in acute appendicitis than males (M:F = 1:1.15) while males predominated in appendicular perforation $(\mathrm{M}: \mathrm{F}=3: 1)$. Appendicitis was more common in the age group of 21-40 years (40\%) where as patients with appendicular perforation presented mostly in the age group of 21-30 years $(7.2 \%)$

Clinical diagnosis was found to be accurate in $91.2 \%$ of cases and hence the rate of negative laparotomies for acute appendicitis in our study was only $8.8 \%$. Out of 11 patients who were histopathological negative, $8 \quad(72.7 \%)$ were females and $3(27.3 \%)$ were males indicating that negative appendectomies were more in females. Among 114 patients reported to be positive on histopathological examination, $86(68.8 \%)$ cases were reported to have features of acute appendicitis, rest $28(22.4 \%)$ cases were having complications of appendicitis (i.e. 10 cases of gangrenous appendicitis and 18 cases of perforated appendicitis.)
The sensitivity, specificity, predictive value of positive test and predictive value of negative test of WBC in uncomplicated acute appendicitis in our study was $78.95 \%, 54.55 \%, 94.74 \%$ and $20 \%$ respectively. In our study, association of WBC count and acute appendicitis had shown to be statistically significant. But it cannot replace surgeons' clinical acumen. However, the association of WBC count in gangrenous or perforated appendicitis was very low as the sensitivity, specificity, positive predictive value and negative predictive value were $21.43 \%$, $2.33 \%, 6.67 \%$ and $8.33 \%$ respectively.

The sensitivity, specificity, predictive value of positive, predictive value of negative test of total serum bilirubin in uncomplicated appendicitis in our study was $57.02 \%, 81.82 \%, 97.01 \%$ and $15.52 \%$ respectively. But the sensitivity, specificity, predictive value of positive, predictive value of negative test of bilirubin in gangrenous or perforated appendicitis in our study was $89.29 \%$, $53.49 \%, 38.46 \%$ and $93.88 \%$ respectively. Thus raised serum bilirubin value had significant association in both complicated and uncomplicated appendicitis.

Hence, from the above discussion it could be impiled that serum bilirubin was a better predictor of perforation in acute appendicitis. However, it lagged behind total WBC count in diagnosisng uncomplicated appendicitis.

The sensitivity, specificity, predictive value of positive test and predictive value of negative test of USG abdomen and abdomen in my study was $92.98 \%, 72.72 \%, 97.25 \%$ and $50 \%$. USG abdomen and pelvis was an accurate, safe and reliable method in the diagnosis of suspected cases of acute appendicitis. Women particularly benefieted most from preoperative imaging, with significant reduction in negative appendicectomy rate than in those who underwent no preoperative investigation. Ultrasonography was useful in ruling out alternate diagnosis, and required the skill of an experienced sonologist and adequate equipment. It added to the cost of patient care. 
The overall prognosis after appendectomy was good with the exception of few local complications like minor wound infection $(13.15 \%)$, wound sepsis $(8.77 \%)$, prolonged ileus (4.38\%), pulmonary complications and delayed intestinal obstruction (1.75\% each). However, there was no mortality in the study group.

Acute appendicitis remains a diagnosed based primarily on history and clinical examination. Clinical examination is indispensable in diagnosing acute appendicitis and all the above investigations can only complement clinical skills but cannot replace it.

The present study clearly demonstrated the high specificity and sensitivity which may be used as a marker for early diagnosis of appendicular perforation and its immediate management to prevent all sorts of possible complications of perforation including its fatalities in both the extremes of age.

\section{Bibliography}

1. Bickell NA, Aufses AH, Rojas M. Et al. (2006) How time affects the risk of rupture in appendicitis. J Am Coll Surg 202:401406.

2. Kearney D, Cahill RA, O'Brien E, et al. (2008) Influence of delays on perforation risk in adults with acute appendicitis. Dis Colon Rectum 51:1823-1827.

3. Anderson RE, Hugander AP, Ghazi SH, et al. (1999) Diagnostic value disease history, clinical presentation, and inflammatory parameters of appendicitis. World J Surg 23:133-140.

4. Bergeron E (2006) Clinical judgement remains of great value in the diagnosis of acute appendicitis. Can J Surg 49:96-100.

5. Kin CJ, Chen JD, Tiu CM, et al. (2005) Can ruptured appendicitis be detected preoperatively in the ED? Am J Emerg Med 23:60-66.

6. Wang P and Chaudhary IH. Mechanism of hepatocellular dysfunction during hyper dynamic sepsis. Am J Physiol Regul Integr
Comp Physiol 1996: 270:927-38 \& 36361.

7. Estrada JJ, Petrosyan M. Barnhart J. et. Al (2007) Hyperbilirubinemia in appendicitis: A new predictor of perforation. $\mathbf{J}$ Gastrointest Surg 11:714-718.

8. Bennion RS. Baron EJ, Thompson JE, et al. (1990) The bacteriology of gangrenous and perforated appendicitis - Revisited. Ann Surg 211:165-171.

9. Vesalius A. De Humani Corporis fabrics Liber V. Basel, Switzerland: Johanes Oporinu; 1543.

10. Bailey and Love's Short Practice of Surgery: $25^{\text {th }}$ ed. Christopher J.K. Bulstrode, Norman S. Williams, P. RonanO'Connell (Ed); (2008), Ch. 67: The vermiform appendix; p. 1204-17.

11. Friffiths EA et al. Bifid vermiform appendix, Curr Surg 2006 May - Jun; 63(3); 176-8

12. Uriev $\mathrm{L}$ et al. Triple-barrelled type of appendical triplication: Ann Diagn Pathol: 2006 June; 10(3): 160-1.

13. Basta M. Morton N E, Mulvilli J J et al. Inheritance of acute appendicitis: familial aggregation and evidence of polygenic transmission. Am J Hum Gent 1990; 46:377-82.

14. Koepsell T D: Factors affecting perforation in acute appendicitis; Surg Gynaecol Obs; 153:508, 1981.

15. Jackson RH; Parents, family doctors and acute appendicitis in childhood; Br Med J; 2:227, 1963.

16. Anderson A. Berghdahl L: acute appendicitis in patients over sixty. Am J Surg. 44:445, 1978.

17. Owen BJ and Harmit HF: Appendicitis in elderly. Ann Surg. 187:392, 1978.

18. Peltokallio P. Tykka H: Evolution of the age distribution and mortality of acute appendicitis. Arch Surg. 116:153, 1981. 
19. Short (1920): Quoted by Burkitt DP: Etiology of appendicitis, $\mathrm{Br} \mathrm{J}$ Surg. 58:695, 1971.

20. Burkitt DP: Etiology of appendicitis, Br J Surg. 58:695, 1971.

21. D Adamis, E Roma Giannikou, K Karamolegou et al: Fibre intake and childhood appendicitis. Int $\mathbf{J}$ of Food Sci and Nutr. Vol 51, Issue 3, May 2000.

22. Pieper R, Kager L et al: Acute appendicitis, a clinical study of 1018 cases of emergency appendectomy. Act Chir Scand. 148:39-63, 1982.

23. Shepherd J: Surgery of the acute abdomen: $1^{\text {st }}$ edition, p.401-501, 1960.

24. Holt $\mathrm{P}$, Legionnaire's disease and abscess: Treatment of Appendix, Br Med J. 2:103, 1981.

25. Tobe $\mathrm{T}$ : Inapparent virus infection as a trigger of appendicitis, The Lancet 1: 1343, 1965.

26. Arnbjornsson E: Varying frequency of acute appendicitis in different phases of menstrual cycles, Surg Gynaecol Obs. 155:709, 1982.

27. Tracey M, Fletcher HS. Apppendicitis in pregnancy. Am J Surg, 2000; 66:555-9.

28. Wangansteen $\mathrm{OH}$, Bowers $\mathrm{WF}$ et al: Significance of the obstructive factor in the genesis of acute appendicitis, an experimental study. Arch Surg. 34: 496, 1937.

29. Shield R: the absorption of secretion of electrolytes and fluid by obstructed bowel; Br J Surg. 52:74, 1965.

30. Storer EH: Appendix from: Principles of Surgery, Edited by Schwartz S. 1, $5^{\text {th }}$ Edition; Br J Surg. 52:74, 1995.

31. Almond et al: Unpublished data, Department of surgical pathology, Washington University School of Medicine, 1956 (from Ackerman's surgical pathology: $5^{\text {th }}$ edition p. 489 , 1981).
32. Horton LW: Etiology of appendicitis: $\mathrm{Br}$ Med J 2: 1672, 1977.

33. Condon RE: Appendicitis in: Textbook of Surgery; $13^{\text {th }}$ Edition, 967-983, 1986.

34. Leigh DA Simons K, Norman E: Bacterial flora of the appendix fossa in appendicitis and post operative infection. J Clin Patho, 27: 997, 1974.

35. Duzgun AP, Munevver Moran, Seluk Uzun et al: Unusual findings in appedicectomy specimens: Evaluation of 2458 cases and review of literature.

36. Adebamowo CA, Akang EE, Lodipo JK: Schistosomiasis of the appendix, Br J Surg 1991; 78: 1219-21.

37. Johnson JR: Etiology of appendicitis. $\mathrm{Br}$ Med J 1:305, 1978.

38. Azzie G, Salloum A. Beasley S. Et al. The complication rate and outcomes of laparoscopic appndicectomy in children with perforated appendicitis. Paediatric Endosurgery Innovative technique 2004; 8 (10): $19-23$.

39. Amyand C. Of an inguinal rupture, with a pin in the appendix cacci, incrusted with stone, and some observation on wounds in the guts. Philos Trans R Soc Lond 1736: 39: $329-342$.

40. Tsoulfas G, Howe JR. Amyand's hernia: Appendicitis in an incarcerated hernia. Surg Rounds 2004: 27:515 - 517.

41. Tait L. Surgical treatment of typhlitis. Birmingham Med Rev 1890; 27:26-34.

42. Fitz RH. Perforating inflammation of the vermiform appendix; with special reference to its early diagnosis and treatment. Am J Med Sci 1886; 92:321 346.

43. McBurney CM. Experience with early operative interference in cases of disease of the vermiform appendix. N Y Med J $1889 ; 50: 676-684$.

44. Treves F. A series of cases of relapsing typhilitis treated by operation, BMJ 1893; $835-837$. 
45. Addiss DG, Shaffer N. Fowler BS. Tauxe RV. The epidemiology of appendicitis and appendectomy in the United States. Am J Epidemiol 1990; 132:910 - 925 (PubMed: 2239906).

46. Cannova JV, Krummen DM, Nicholson O. Pneumoperitoneum in association with perforated appendicitis. Am Surg 1995; 61: 324-325.

47. Sand M, Bechara FG, Holland-Letz T et al: Diagnositc value of hyperbilirubinaemia as a predictive factor for appendiceal perforation in acute appendicitis, Am J Surg 2009; 198: 193-198.

48. Korner H. Sondenna K. Soreide JA, et al: Incidence of acute non perforated and perforated appendicitis: age-specific and sex-specific analysis. World J Surg 1997; $21: 313-317$.

49. Chipponi J. Appendicities. In: Favniez PL, Houssin D, eds. Pathologie Chirurugicale: Chirurigie Digestive et Thoracique. Paris: Masson, 1991: 253-260.

50. Hale DA. Molloy M. Pearl R. Schutt DC, Jaques DP. Appendectomy. A contemporary appraisal. Ann Surg 1997; 225: 252-261.

51. Oberlin P. Valette M. Malafosse M. Pneumoperitonie et peritonite appendiculaire. Gastroenterol Clin Biol 1981; 5: 287-289.

52. Newman B, Nussbaum A. Kirkpatrick JA jun. Colodny A. Appendiceal perforation, pneumoperitoneum, and Hirschsprung's disease. J Pediatr Surg 1988; 23: 854-856.

53. Alvarado A. A practical score for the early diagnosis of acute appendicitis. Ann Emerg med 1986; 15:557-564 (PubMed: 3963537).

54. Saidi RF, Ghasemi M. Role of Alvarado score in diagnosis and treatment of suspected acute appendicitis. Am J Emerg Med 2000; 18:230-231 (PubMed:107509411).
55. Baril N, Wren S. Radin R et al. The role of anticoagulation in pylephlebitis. Am J Surg 1996; 172:449-452 (PubMed: 89425242).

56. Elangovan S. Clinical and laboratory findings in acute appendicitis in the elderly. J Am Board Fam Pract. 1996; 9:75-8.

57. Salamat Khan: The diagnostic value of hyperbilirubinaemia and total leucocyte count in the evaluation of acute appendicitis. Journal of Clinical and Diagnostic Research (serial online) 2009 August (cited: 2009 August 7); 3:16471652.

58. Atahan K. Ureyen O, Aslan E et al: Preoperative diagnostic role of hyperbilirubinaemia as a marker of appendix perforation. The $\mathrm{J}$ Intern Med Research 2011; 39: 609-618.

59. Marcelo A. Beltran, Pedro E. Mendez et al: Is hyperbilirubinaemia in appendicitis a better predictor of perforation than $\mathrm{C}$ reactive protein? - prospective study; Indian J Surg (September- October 2009) 71:265-272.

60. Andrew Emmanuel1,2 Peter Murchan2, Ian Wilson, Paul Balfel: The value of hyperbilirubinaemia in the diagnosis of acute appendicitis; Ann R Coll Surg Engl 2011; 93: 213-217.

61. Swasso RD, Hanna EA, Moore DL. Leukocytic and neutrophilic counts in the acute appendicitis. Am J surj 1970; 120:563-6.

62. Coleman C, Thomson J, Bennion R, Schmit P. White Blood Cell count is a poor predictor of severity of disease in diagnosis of appendicitis. Am Surg 1998; 64 (10): 983-5.

63. Doraiswamy NV. Leucocyte counts in the diagnosis and prognosis of acute appendicitis in children. Br J Surg 1979; 66:782. 
64. Vermeulen B, Morabia A. Unger PP. Influence of white cell count on surgical decision making in patients with abdominal pain in the right lower quadrant. Eur J Surg 1995; 161:483-6.

65. Schwartz's principles of surgery; F. Charles Brunicardi, MD, FAS (Ed); $9^{\text {th }}$ ed; Mc Graw Hill; 2010; Ch. 30: The Appendix; p 1073-90.

66. Tillet W, Francis T. Serological reactions in pneumonia with non-protein somatic fraction of pneumococcus. 1930; 52:561.

67. Gurleyik E, Gurleyik G. Unalmiser S. Accuracy of serum of C-reactive protein measurements in diagnosis of acute appendicitis compared with surgeon's clinical impression. Dis Colon Rectum 1995 Dec: 38 (12):1270-4.

68. Gronroos M and Gronroos P. leucocyte count and C- reactive protein in the diagnosis of acute appendicitis. BJS 1999; 86: 501-4.

69. Shakhatresh HS. The accuracy of Creactive protein in the diagnosis of acute appendicitis compared with that of clinical diagnosis. Med Arh 2000; 54(2):109-10.

70. Asfar S. Safar H, Khoursheed M. Dasthi $\mathrm{H}$, Al-Bader A. Would measurement of Creative protein reduce the rate of negative exploration for acute appendicitis? J R Coll Surg Edinb Feb 2000; 45:21-4.

71. Ducholm S. Bagi P. Bud M. Laboratory aid in the diagnosis of acute appendicitis. A blinded, prospective trial concerning diagnostic value of leukocyte count neutrophil differential count, and Creactive protein. Dis colon rectum 1989 Oct; 32(10):855-9.

72. Oosterhuis WP, Zwinderman $\mathrm{AH}$, Teeuwen M, van Andel G. Oldenziel H, Kerkhoff JF et al. $\mathrm{C}$ reactive protein in the diagnosis of acute appendicitis. Eur J Surg 1993 Feb; 1599(2):115-9.

73. Eriksson S, Olander B, Pira U, Granstorm L. White blood cell count, leucocyte elastase activity, and serum concentrations of interleukin-6 and C-reactive protein after open appendicectomy. Eur J Surg 1997; 163:123-7.

74. Thimsen DA, Tong GK, Gruen DA, Tong GK, Gruenburg JC. Prospective evaluation of C- reactive protein in patients suspected to have acute appendicitis. Am Surg 1989 Jul; 55(7):466-8.

75. Al-Saigh AH. C-reactive protein in the differentital diagnosis of the acute abdomen especially acute appendicitis. J R Coll Surg Edinb 1992 Aug; 37(4):238-40.

76. Davies AH. Bernau F. Salisbury A, souter RG. C -reactive protein in right iliac fossa pain. JR Coll Surg Ednib 1991 Aug; 36(4):242-4.

77. Marchand A. Van Lente F. Galen RS. The assessment of laboratory tests in the diagnosis of acute appendicitis. Am J Clin Pathol 1983 Sep; 80(3):369-74.

78. Mikaelsson C, Arnbjornsson F. The value of $\mathrm{C}-$ reactive protein (CRP) determinations in patients with suspected acute appendicitis. Ann Gynaecol. 1984; 73(5):281-4.

79. Brooks DW, Killen DA, Roentgenorgraphic findings in acute appendicitis. Surgery. 1965; 57:377.

80. Jona JZ, Belin RP, Selke AC. Barium enema as a diagnostic aid in children with right lower quadrant pain J A M A 1981; 245; 505-648.

81. Stephanic R Wilson; Gastrointestinal system in; diagnostic ultrasound Carol $\mathrm{M}$ Rumack M.D. Stephanic R Wilson. J William Chorboneau M.D (ed) $3^{\text {rd }}$ edition Mosby 2005 VOl I.

82. Clive A Barrtan ;GIT Large bowel; Diagnostic Radiology A Textbook of Medical Imaging ;R.G Granger, D.J. Allison (Ed) $3^{\text {rd }}$ edition; Mosby; VOL II SEC IV 1042 chapter 50.

83. Lee HJ, Jeong YK, Hwang JC, Ham SY, Yang SO. Graded compression 
sonography with adjuvant use of a posterior manual compression technique in the sonographic diagnosis of acute appendicitis. AJR AM J Roentgenol. 2002; 178:863-8.

84. Patriquin HB, Garcier JM, Lafortune M et al. Appendicitis in children and young adults. Doppler sonographic - pathologic correlation. AJR Am J Roentgenol 1996; 166:629-33.

85. Nesterenko IuA, Grinberg AA, Shapovaliants SG, Mikhailusov SV, Drozdov GE, Maksimova VV. Ultrasound diagnosis of acute appendicitis; Khirurgiia (Mosk). 1994 Jul; (7):26-9.

86. West WM, Brady-West DC, McDonald AH, Hanchard B, Fearon-Boothe, Ultrsound and white blood cell counts in suspected acute appendicitis. West Indian Med J 2006 Mar; 55(2):100-2.

87. Uebel P. Weissis H. Trimborn CP, FiedlerL. Bersch W; Ultrasound diagnosis of acute appendicitis-possibilities and limits of the method-results of prospective and retrospective clinical studies; Ultraschall Med. 1996 Jun;17(3):100-5.

88. Shirazi, A.S., M. Sametzadeh, R. Kamankesh and F. Rahim, 2010. Accuracy of sonography in diagnosis of acute appendicitis running. Pak J Biol Sciences, 13:190-3.

89. CDR David S. Wade, MC, USN; Stephen E. Morrow, MD; Zubin N. Balsara, MD: Thomas K Burkhard, MD; Walter B. Goff, DO; Accuracy of Ultrasound in the Diagnosis of Acute Appendicitis Compared with the Surgeon's Clinical Impression; Arch Surg. 1993; 128(9):1039-46.

90. J.A. Worrell, L. F. Drolshagen, T. C. Kelly, D. W. Hunton, G.R. Durmon and AC Fleischer; Graded compression ultrasound in the diagnosis of appendicitis. A comparison of diagnostic criteria.
Journal of Ultrasound in Medicine 1990; 9(3):145-50.

91. HS Fung. S Lau, JCW Siu, CM Chan, SCH Chan; Audit of Ultrasonography for Diagnosis of Acute Appendicitis Retrospective Study; J HK Coll Radiol. 2008; 11: 108-11.

92. Shryl-Chryl Chen, MD, Kai-Mo Chen, MD, Shih-Ming Wang MD. Abdominal Sonography screening of clinically diagnosed or suspected appendicitis before surgery. World Journal of Surgery 1998; 22:419-51.

93. Incesu L. Coskun A, Seleuk M.B et al. MR imaging and sonographic correlation. AJR Am J Roentegenol 1997; 168: 669-74.

94. Kipper SL, Rypins EB, Evans DG et al. Neutrophil-specific 99m Tc-labeled antiCD15 monoclonal antibody imaging for diagnosis of equivocal appendicitis. J Nucl Med 2000; 41:449-55.

95. Paterson-Brown S. Thompson JN, et al. Which patients with suspected apeendicitis should undergo laparoscopy? Br Med J 1988; 296-363.

96. Kalan M., Rich AJ., Talbot D., Cunliffe WJ.; Evaluation of the modified Alvarado score in the diagnosis of acute appendicitis: a prospective study. Ann R. Coll. Surg. Engl 1994; 76:418-9.

97. Sabiston Text Book of Surgery. The biological basis of modern surgical practice. $19^{\text {th }}$ ed., T M Townsend et al. Ch. 51: The Appendix: p. 1279-93, 2012.

98. Harrisons Text book of Internal Medicine (Vol. II). D. Longo. S. Faucci, Danis L Kasper, et al. Eds published by Mac Graw Hill, Medical Publishing Division. $18^{\text {th }}$ International edition, Ch. 303: The hyperbilirubinaemias; p.2531-37:2012.

99. Khan S. Evaluation of hyperbilirubinaemia in acute inflammation of appendix: A prospective study of 45 cases; Kathamandu Univ Med J (2006), Vol. 4, No. 3, Issue 15, 281-289. 
100. Joaquin J. Estrada et al. Hyperibilirubinaemia in Appendicitis: A New Predictor of Perforation. Journal of Gastrointestinal Surgery (2007) 11:714718.

101. Khan MN. Davie E, Irshad K: The role of white cell count and C-reactive protein in the diagnosis of acute appendicitis. J Ayub Med Coll Abbottabad 2004; 16: 17-19.

102. Hoffman J. Rasmussen OO; Aids in the diagnosis of acute appendicitis. Br. J Surg 1989; 76: 774-779.

103. Zoller WG, Kellner H. Schwerk WB; Value of ultrasound in diagnosis of acute appendicitis; Bildgeburg, 1996 Jun; 63(2): 78-82. 